\title{
OKAPI, an Emotional Education and Classroom Climate Improvement Program Based on Cooperative Learning: Design, Implementation, and Evaluation
}

\author{
Maria-Jose Mira-Galvañ * and Raquel Gilar-Cobi *(D) \\ Department of Developmental Psychology and Didactics, University of Alicante, 03080 Alicante, Spain \\ * Correspondence: jose.galvan@ua.es (M.-J.M.-G.); raquel.gilar@ua.es (R.G.-C.)
}

check for

updates

Citation: Mira-Galvañ, M.-J.; Gilar-Cobi, R. OKAPI, an Emotional Education and Classroom Climate Improvement Program Based on Cooperative Learning: Design, Implementation, and Evaluation. Sustainability 2021, 13, 12559.

https://doi.org/10.3390/su132212559

Academic Editor: Cecilia

Ruiz Esteban

Received: 29 September 2021

Accepted: 11 November 2021

Published: 13 November 2021

Publisher's Note: MDPI stays neutral with regard to jurisdictional claims in published maps and institutional affiliations.

Copyright: (c) 2021 by the authors. Licensee MDPI, Basel, Switzerland. This article is an open access article distributed under the terms and conditions of the Creative Commons Attribution (CC BY) license (https:/ / creativecommons.org/licenses/by/ $4.0 /)$.

\begin{abstract}
A positive school climate can directly influence the relationships and social interactions among students while also contributing to the development of socio-emotional skills. Simultaneously, the school climate depends on these said skills. Despite this close relationship, emotional education and school climate improvement programmes have traditionally been studied separately. This study describes and evaluates the effectiveness of a new programme, OKAPI (Organisation, Cooperation, Positive Environment, Participation and Emotional Intelligence), for the development of socioemotional skills and the improvement of classroom climate for primary school students using a cooperative learning methodology. The total sample comprised 86 students aged 9-11 years. A quasi-experimental design with pre-test and post-test measures with a control group was used. The results show that the program's implementation is effective both for the improvement of the classroom climate and the acquisition of training in the field of emotional intelligence, as well as for the development of cooperative competences. Among the fundamental pillars of the OKAPI programme are its simplicity and transversality, so that teachers are responsible for its application and monitoring; thus, the programme becomes an agent of change in their educational practice.
\end{abstract}

Keywords: emotional education; classroom climate; cooperative learning; intervention program; quasi-experimental design; primary education

\section{Introduction}

In recent decades, the amount of research on programmes for the development of socioemotional skills in schools has increased considerably, showing a positive relationship with various aspects such as academic performance [1-9], greater ability to perceive, understand, and control one's emotions [10,11], decreased disruptive behaviours [7,12], and greater psychological well-being [13-15], among others. Unfortunately, the implementation of these programmes has not always yielded the expected results as they have not been fully integrated into school and classroom life as cross-curricular tools [16,17].

A positive school climate can directly influence the relationships and social interactions among students while also contributing to the development of socioemotional skills. Simultaneously, the school climate depends on these said skills $[18,19]$. Despite this close relationship between school climate and socioemotional competencies, emotional education and school climate improvement programmes have traditionally been studied separately [20], creating different research bodies and hindering the opportunity to create synergies. Fortunately, a change in this situation has begun, and studies are increasingly being conducted in a coordinated manner.

This trend demonstrates the willingness to incorporate programmes that coordinate efforts to improve the school climate and the development of socioemotional skills, and it is in this line of work that this research is framed. Specifically, the OKAPI (Organisation, Cooperation, Positive Environment, Participation and Emotional Intelligence) programme for primary schools has been designed, created, and implemented for this research. 
OKAPI is based on the Bar-On model [21], in the field of EI, and on the curricular contents of emotional education proposed by Bisquerra [22]. Moreover, regarding the school and class climate, it is conceptualized as having a global character [23] of a multidimensional nature, which includes social interactions, the methodology used in classes, the culture and values of the school, and interactions with the learning space, among others $[24,25]$. Of particular importance in the programme is a change in the methodological paradigm oriented towards cooperative learning, based on the contributions of Kagan [26], Pujolàs [27], and Pujolàs and Lago [28].

The fundamental objective of the current educational system is the integral education of the students, which proposes, among other things, to pay special attention to social interactions that originate in the classroom [29] in the context and with the effects of these interactions $[30,31]$. Socioemotional education programmes are conducted in a specific context, the centre, as well as the classroom. These environments determine the relationships between community members, while the relationships themselves affect the environment. These two aspects are closely related but have often been addressed separately by both researchers and teachers.

Classroom climate and emotional education are elements that benefit each other. It is necessary to create an inclusive, open, and flexible environment at school that helps promote the development of all student dimensions. Therefore, it is necessary to join forces and propose interventions that consider both aspects.

\subsection{Cooperative Learning}

We must look beyond traditional academic content and employ techniques that affect psychosocial variables [32]. Cooperative learning (CL) is a methodology that allows children and adolescents to internalise the skills, abilities, and values necessary to become effective citizens in a democracy [33]. CL works directly on social skills and values, such as solidarity, understanding and cooperation.

Cooperation is a characteristic of human beings. It is typical of people to think and work cooperatively. As learning is a social activity, we should use a methodology based on a cooperative learning structure in schools [34]. Furthermore, we must not forget the fundamental role that interpersonal relationships play in determining the quantity and quality of school learning.

Several authors have committed to using cooperative learning in the classroom as a methodology and an organisational form capable of responding to the education system's current needs. CL is considered a potentially effective tool for combating poor results at school, enhancing the academic performance and social and cognitive skills of all students, and improving psychosocial factors such as motivation, self-esteem, and positive attitude [32,35]

The school should be a facilitator for the development of social and prosocial skills in students; therefore, establishing a positive classroom environment is fundamental. This can be achieved by improving social cohesion, one of the key areas of cooperative learning. The use of cooperative learning in the classroom improves its climate and atmosphere [36,37], and therefore the coexistence of students. Moreover, it is well known that establishing a good relational environment between students by creating an environment where students can establish cordial relationships with their peers provides a context suitable for learning cognitive and social skills [38].

\subsection{What Is Meant by Classroom or School Climate?}

The school or classroom climate is a complex concept that has evolved from the Moos model $[39,40]$ to the present day. Initially, it referred to more general positions, almost always limited to how the classroom is organised by teachers. However, over time, an increasing number of elements have been incorporated.

Bisquerra [41] indicates that the current approach to the construct is intended to include such different perspectives as teaching skills [42], interpersonal relationships [43], 
social skills [44], teacher socioemotional competence [45], level of coexistence [46] and overall satisfaction [47], among others.

Several studies recognise the existence of a positive school climate as a necessary condition for achieving good academic results $[19,48]$. Certain other studies state that it is directly related to high performance [49] or that it can affect learning improvement [50].

However, apart from academic performance, and continuing with the concept of 'education' raised by the Delors Report (1996) at UNESCO, a positive school climate facilitates well-being and promotes both the personal and integral development of the individual [19,51]. Further, it promotes positive relationships between group members [48], fosters the creation of a spirit of belonging to the group [18], and becomes a protective factor for students with certain disadvantages $[52,53]$.

\subsection{Emotional Education and Classroom Climate: The Current State of the Question}

Research has corroborated the proposition that in a positive school climate, socioemotional and academic competencies have a major impact on peoples' lives and even on their health, especially mental health [16]. However, these have traditionally been studied separately [20].

This disconnect between programmes aimed at improving classroom climate and emotional education programmes may be due to several factors, including lack of financial resources, lack of preparation by teachers, lack of infrastructure on the part of public administration, etc. [54]. It may also be due to the fact that these programmes primarily arise from external research conducted by universities or research centres, and thus the faculty and the educational community do not participate in programme design.

This research aims to respond to this need. To this end, the OKAPI programme was designed to include both approaches (emotional education and school climate) and to be implemented by teachers. It is based on three main pillars: improvement of the classroom climate, emotional education, and cooperative learning.

One of the main goals of the OKAPI programme is to create a positive environment in order to allow the development of everyone's socioemotional competencies in the school environment. The programme encourages the creation of a space where students, through interactions with the educational context, can practice the skills on which they are working. It includes the direct teaching of socioemotional competence, and incorporates tools that can be included in daily routines.

\subsection{OKAPI-Specific Goals and Intervention Aspects}

The key points of the programme, which make the union of the three pillars possible, respond to the acronym of OKAPI in Catalan: $\mathrm{O}$ (classroom organisation), $\mathrm{K}$ (cooperative learning), A (positive class environment), $\mathrm{P}$ (participation of all members of the educational community), and I (emotional education as a key point of the curriculum).

The specific goals, organised as blocks intended to be achieved with the students, are listed in Table 1.

Table 1. OKAPI-specific goals.

\begin{tabular}{cc} 
& \multicolumn{1}{c}{ Be aware of and able to identify and name your own emotions } \\
\cline { 2 - 3 } $\begin{array}{c}\text { EMOTIONAL } \\
\text { AWARENESS }\end{array}$ & $\begin{array}{c}\text { Be able to identify and name the emotions of the people around us } \\
\text { Arouse interest in distinguishing and interpreting our own emotions and } \\
\text { those of the people around us }\end{array}$ \\
\cline { 2 - 3 } & $\begin{array}{c}\text { Develop the ability to evaluate one's emotions and discern between what is } \\
\text { experienced and what is true }\end{array}$ \\
\hline & $\begin{array}{c}\text { Establish a relationship between emotions and the situations that generate } \\
\text { them }\end{array}$
\end{tabular}


Table 1. Cont.

\begin{tabular}{|c|c|}
\hline \multirow{5}{*}{$\begin{array}{l}\text { EMOTIONAL } \\
\text { REGULATION }\end{array}$} & Be able to express one's emotions appropriately in a given context \\
\hline & Develop strategies for dealing with unpleasant emotions \\
\hline & Develop the ability to self-generate positive emotions \\
\hline & Be able to regulate the intensity of one's emotions and reduce impulsivity \\
\hline & $\begin{array}{c}\text { Develop the ability to adjust emotions and behaviour when situations } \\
\text { change }\end{array}$ \\
\hline \multirow{5}{*}{$\begin{array}{l}\text { PERSONAL } \\
\text { AUTONOMY }\end{array}$} & Recognise one's own personal qualities \\
\hline & Identify those aspects, facts, and features that you like or dislike \\
\hline & Develop a positive attitude \\
\hline & Accept yourself and be happy with yourself \\
\hline & Recognise and take responsibility for one's own actions \\
\hline \multirow{5}{*}{$\begin{array}{l}\text { SOCIAL } \\
\text { COMPETENCE }\end{array}$} & Develop active listening \\
\hline & $\begin{array}{l}\text { Master the basic rules of social skills: respect the turn of speech, rules of } \\
\text { courtesy, and look in the other person's face }\end{array}$ \\
\hline & Respect the opinions and emotions of the people around us \\
\hline & $\begin{array}{l}\text { Be able to describe the causes and consequences of conflicts in the } \\
\text { generated relationships }\end{array}$ \\
\hline & Apply positive and constructive strategies to resolve conflicts \\
\hline \multirow{5}{*}{$\begin{array}{c}\text { COMPETENCES } \\
\text { FOR LIFE AND } \\
\text { WELL-BEING }\end{array}$} & Set affordable goals and plans to be able to achieve them \\
\hline & Be able to look for alternatives and help in situations that require it \\
\hline & Be able to make decisions \\
\hline & Develop assertiveness \\
\hline & $\begin{array}{l}\text { Develop an attitude aimed at looking for activities and strategies that are a } \\
\text { source of calmness and energy }\end{array}$ \\
\hline \multirow{5}{*}{$\begin{array}{l}\text { COOPERATIVE } \\
\text { COMPETENCES }\end{array}$} & Be able to work in groups, taking on individual responsibilities \\
\hline & $\begin{array}{l}\text { Identify those aspects that improve communication and those that make it } \\
\text { difficult }\end{array}$ \\
\hline & Generate an active attitude to overcome communication difficulties \\
\hline & Make constructive criticism \\
\hline & Develop an active attitude towards contributing to the group and society \\
\hline \multirow{5}{*}{ CLASS CLIMATE } & Know and respect the rules of coexistence of the centre and the classroom \\
\hline & $\begin{array}{c}\text { Generate awareness in relation to the effect of violent and disruptive } \\
\text { behaviours in school }\end{array}$ \\
\hline & Develop an active attitude towards improving the school climate \\
\hline & $\begin{array}{c}\text { Develop strategies to generate spaces for coexistence and friendship with } \\
\text { colleagues }\end{array}$ \\
\hline & Recognise individual and group similarities and differences \\
\hline
\end{tabular}

To conduct the OKAPI programme, interventions are made in five aspects that correspond to OKAPI's acronym (Table 2). 
Table 2. Aspects of OKAPI's intervention.

\begin{tabular}{|c|c|c|}
\hline Organisation & $\begin{array}{l}- \\
- \\
- \\
-\end{array}$ & $\begin{array}{l}\text { A specific way to organise the space in the classroom } \\
\text { Use of strategies to ensure efficient use of time } \\
\text { Incorporation of routines related to social skills in the classroom } \\
\text { Incorporation of time dedicated to emotional education work and the } \\
\text { different strategies the programme incorporates into the class schedule }\end{array}$ \\
\hline $\begin{array}{l}\text { Cooperative } \\
\text { Learning }\end{array}$ & $\begin{array}{l}- \\
- \\
- \\
-\end{array}$ & $\begin{array}{l}\text { Heterogeneous groups of students } \\
\text { Monitoring and evaluation of groups } \\
\text { Regular use of cooperative structures } \\
\text { Incorporation of roles in the classroom } \\
\text { Systematic work on social cohesion }\end{array}$ \\
\hline Class Climate & $\begin{array}{l}- \\
- \\
-\end{array}$ & $\begin{array}{l}\text { Incorporation of concrete strategies to work in coexistence: clear } \\
\text { expectations, class rules, use of positive points, etc. } \\
\text { Empower students who work to improve coexistence } \\
\text { Use of concrete strategies for conflict resolution: PiP (stop and think) and } \\
\text { VET (evaluate the situation, explore alternatives, use some time to think } \\
\text { carefully) }\end{array}$ \\
\hline Participation & - & $\begin{array}{l}\text { Family involvement: monthly family-school activities, introduction of } \\
\text { volunteering in classrooms, training families in emotional management, } \\
\text { increasing communication with families } \\
\text { Conducting solidarity projects related to the community } \\
\text { Increasing student participation in the classroom }\end{array}$ \\
\hline $\begin{array}{l}\text { Emotional } \\
\text { Intelligence }\end{array}$ & $\begin{array}{l}- \\
- \\
- \\
-\end{array}$ & $\begin{array}{l}\text { Holding assemblies in the classroom: starting circle, exit circle, and weekly } \\
\text { classroom meeting } \\
\text { Daily incorporation of relaxation and meditation in the classroom } \\
\text { Use of the mood metre } \\
\text { Use of the MENU strategy (a list of different strategies organised by steps } \\
\text { using visual clues) as a guide for students to resolve conflicts } \\
\text { Direct instruction of emotional education, } 30 \text { min per week. } \\
\text { Use of the CiC (tell and change) strategy: readings related to emotional } \\
\text { education with a linguistic approach } \\
\text { Work on the vocabulary of emotions once a week }\end{array}$ \\
\hline
\end{tabular}

\subsection{Objectives and Hypotheses}

This research aims to design, implement, and evaluate the effectiveness of a programme for the development of socioemotional skills and improvement of the classroom climate for primary school students by using a cooperative learning methodology. below:

The specific objectives of the study and the hypotheses derived from them are detailed

- Specific objective 1: Analyse the changes produced in the participants, evaluated by whether they are included in the experimental group or the control group, in terms of socioemotional competences after application of the intervention programme.

Hypothesis 1: The experimental group significantly improves the development of socio-emotional skills post-test; differences related to participation in the intervention programme are identified.

- Specific objective 2: Analyse the changes produced in the participants, evaluated according to whether they are included in the experimental group or the control group, in terms of the effectiveness of the cooperative work after application of the intervention programme.

Hypothesis 2: The experimental group achieves a significant improvement in the effectiveness of cooperative work post-test; differences linked to participation in the intervention programme are identified. 
- Specific objective 3: Analyse the changes produced in the study participants, evaluated according to whether they are included in the experimental group or the control group, in relation to the class climate perceived after application of the intervention programme.

Hypothesis 3: The experimental group shows a significant improvement in perceived class climate post-test; differences related to participation in the intervention programme are identified.

In the following section, the study carried out is described indicating the participants, measuring instruments, procedure and obtained results regarding the analysis of the effectiveness of the OKAPI programme. The results are then discussed in order to extract the main conclusions and practical applications of the study.

\section{Materials and Methods}

\subsection{Participants}

The intervention programme was aimed at students aged 9-11 years. Five schools attended a meeting to present the program, and four of them volunteered to participate in the research. Finally, two different schools from Alicante province, Spain, were selected to participate in the program. Both schools share similar characteristics: they only have one unit of each level, are both located in the same area, and have had an increase in discipline problems in recent years. A total of 45 students from one school were in the intervention group, and 41 students from the other school were in the control group. The total sample comprised 86 students.

\subsection{Measures}

The instruments used for measurement were as follows:

- Emotional intelligence was measured by EQ: i: YV (S) [21]. This is a self-reported measure that assesses students' perceptions of their own socioemotional competence. The instrument included 30 items with a 4-point Likert scale $(1=$ not true of me, $2=$ a little true in my case, $3=$ true in my case, $4=$ very true). The scale is composed of five-factors: intrapersonal (for example: some things make me very angry), interpersonal (I care what happens to other people), stress management (some things annoy me a lot), adaptability (I like every person that I meet), and mood (Nothing bothers me). A total scale score and a score for each dimension were given. The reliability values using Cronbach's alpha were as follows: interpersonal $(\alpha=0.67)$; intrapersonal $(\alpha=0.84)$; stress management $(\alpha=0.84)$; adaptability $(\alpha=0.83)$; and the questionnaire in general $(\alpha=0.77)$ [55].

- Classroom climate was assessed using the Scale for the Assessment of the Social Classroom Climate in primary school students [56]. This is self-reported measure that assesses students' perceptions of the social climate in the classroom. The instrument included 12 items with a 4 -point Likert scale $(1=$ never, $2=$ sometimes, $3=$ many times, 4 = always). The scale is composed of four dimensions: interest (for example: Teachers take a personal interest in us), relationship (The relationship between teachers and students is good), satisfaction (The students are happy with the group) and communication (In this class there is very good communication between us). A total scale score and a score for each dimension were given. Regarding the primary scale, the items corresponding to factor 1 , relationship, interest, and communication $(\alpha=0.8149)$ and factor 2 , cohesion and satisfaction of the group $(\alpha=0.82015)$ were used [56].

- Cooperative competencies were assessed using the Cooperative Learning Efficiency scale [57] The scale has two dimensions or explanatory factors: interdependence/responsibility and communication. The first factor refers to the perception that each team member has of their colleagues in terms of responsibility and interdependence in cooperative activities. An example of such an item is: Every student contributes to the team. The second factor assesses the communication skills used by peers during cooperative learning activities. An example of this item is: In the group, students listen to each other. 
A total scale score and a score for each dimension were given. The internal consistency of the scale was highly acceptable, assuming a Cronbach's alpha value of 900 [57].

- A programme evaluation questionnaire was developed specifically for this research. A questionnaire was prepared in order to determine the degree to which the objectives of the program were fulfilled. The questionnaire included seven items with a 5-point Likert scale ( $1=$ never, $2=$ sometimes, $3=$ many times, $4=$ always). This questionnaire was answered both before and after the implementation of the programme. In the questionnaire, three items referred to aspects related to the organisation and management of the classroom, one item referred to cooperation, two items evaluated the classroom climate and coexistence as an item of participation, and one item referred to the work of emotional intelligence in class.

- A teacher satisfaction questionnaire was developed specifically for this research. The questionnaire included 10 items with a 5-point Likert scale $(1=$ never, $2=$ sometimes, $3=$ many times, $4=$ always). The questionnaire included items on the interest and usefulness of the content worked on in the program, namely, class climate, cooperative learning and emotional intelligence. It also included items referring to the program's structure, the training received, and the materials used. Open questions were also be asked about different aspects of the OKAPI programme.

\subsection{Procedure}

The implementation of the programme took place in 2018. Prior to the implementation of the study, all participants (principals, teachers, and parents) provided written informed consent in accordance with the Declaration of Helsinki and the recommendations and approval of the University of Alicante Ethics Committee (UA-2015-07-06). The commitment to confidentiality with respect to all data obtained from both teachers and students was guaranteed.

OKAPI is a multi-year program; however, in this research we provide information about only one year of application. While this was not a top-down initiative (that is, it did not start from the educational authorities), we had the support of the teacher training centre.

The principal of the centre and the teaching staff participating in the research both engaged in a specific training programme the year before the implementation of the OKAPI programme.

The training course was conducted in ten sessions ( $20 \mathrm{~h}$ in total) including the following elements: cooperative learning, emotional education, classroom organisation, strategies to improve the classroom climate, and the importance of the educational community's participation at the school.

The quasi-experimental study was conducted during the school year, from September to June. In September and October, several meetings were held with the teachers of the intervention group to organise all the strategies and activities required for programme implementation. The pre-test was administrated to the experimental and control groups in November, and the post-test was administrated in June. Thus, the implementation of the OKAPI programme in the experimental group took place from December to June, while the control group received normal teaching.

During programme implementation, the teachers of the intervention group received monthly training to conduct the different strategies. Although the OKAPI programme was applied by the teachers, the main researchers also attended a minimum of three weekly sessions in order to support them and to help conduct emotional education direct training. Simultaneously, a self-evaluation of the degree of programme implementation was conducted monthly by the teaching staff. 


\subsection{Design and Data Analysis}

A quasi-experimental design with pre-test and post-test measures with a non-equivalent control group was used [58] This is a quasi-experimental design, as the groups were formed naturally and not randomly.

In order to determine programme effectiveness, the MLG (General Linear Model) of repeated measures has been used, wherein groups of related dependent variables representing different measures of the same attribute are analysed [59-62]. In this analysis, at least one of the factors is based on independent observations, and at least one other is based on correlated observations [63]. Graphs of the conducted interactions are also provided in order to visually represent the differences obtained between the intervention and control groups as well as in the pre-test and post-test situations, and to analyse the meaning of any differences.

The descriptive statistics of the program evaluation questionnaire and the teacher satisfaction questionnaire answered by the tutors of the classes that made up the intervention group were also analysed.

\section{Results}

Box's $\mathrm{M}$ test showed the homogeneity of the variance-covariance matrix for the following: intrapersonal (EI) scale $(\mathrm{F}=2.31 ; \mathrm{gl}=1,777,031.74 ; p=0.07)$; interdependenceresponsibility dimension $(\mathrm{CL})(\mathrm{F}=1.12 ; \mathrm{gl}=1,777,031.74 ; p=0.34)$; communication dimension $(\mathrm{CL})(\mathrm{F}=11.14 ; \mathrm{gl}=1,777,031.74 ; p=0.34)$; class climate dimension $(\mathrm{F}=2.43$; $\mathrm{gl}=1,777,031.74 ; p=0.06)$; and class climate communication dimension $(\mathrm{F}=0.80 ; \mathrm{gl}=1,777,031.74$; $p=0.49$ ). The assumed homogeneity of the variance-covariance matrices was rejected for the following: adaptability (EI) $(\mathrm{F}=5.22, \mathrm{gl}=1,777,031.74 ; p<0.001)$; stress management (EI) $(\mathrm{F}=4.96 ; \mathrm{gl}=1,777,031.74 ; p<0.001) ; \operatorname{mood}(\mathrm{EI})(\mathrm{F}=7.68 ; \mathrm{gl}=1,777,031.74 ; p<0.001)$; cooperative learning total $(\mathrm{F}=3.21 ; \mathrm{gl}=1,777,031.74 ; p=0.02)$; total class climate $(\mathrm{F}=3.10$; $\mathrm{gl}=1,777,031.74 ; p=0.02)$; class climate interest dimension $(\mathrm{F}=16.77 ; \mathrm{gl}=1,777,031.74$; $p<0.001)$; and class climate satisfaction dimension ( $\mathrm{F}=7.58 ; \mathrm{gl}=1,777,031.74 ; p<0.001)$. However, as it is a sample with two groups with a similar number of participants, the violation of the assumption has minimal effect [64].

Univariate analysis revealed, as shown in Table 3, that the interaction between evaluation time (pre-test and post-test) and training was significant for most of the variables.

Table 3. Summary of intra- and inter-subject univariate ANOVA.

\begin{tabular}{|c|c|c|c|c|c|c|c|c|c|}
\hline & \multirow[b]{2}{*}{ Source } & \multirow[b]{2}{*}{ Type III } & \multirow[b]{2}{*}{ df } & \multirow[b]{2}{*}{$\mathbf{F}$} & \multirow[b]{2}{*}{ Sig. } & \multirow[b]{2}{*}{$\eta^{2}$ Partial } & \multirow[b]{2}{*}{$\begin{array}{c}\text { Observed } \\
\text { Power }\end{array}$} & \multicolumn{2}{|c|}{ Multiple Comparisons } \\
\hline & & & & & & & & $\begin{array}{c}\text { Group Mean } \\
\text { Difference } \\
\text { (s.e.) }\end{array}$ & $\begin{array}{c}\text { Factor } 1 \text { Mean } \\
\text { Difference } \\
\text { (s.e.) }\end{array}$ \\
\hline \multirow{5}{*}{ Intrapersonal } & Intra & 155.91 & 1 & 17.36 & $<0.001$ & 0.17 & 0.98 & $0.49(0.56)$ & $-1.90 *(0.45)$ \\
\hline & Intra * Inter & 98.61 & 1 & 10.98 & 0.001 & 0.11 & 0.90 & & \\
\hline & Error Intra & 754.36 & 84 & & & & & & \\
\hline & Inter & 10.69 & 1 & 0.79 & 0.37 & 0.01 & 0.14 & & \\
\hline & Error Inter & 1140.42 & 84 & & & & & & \\
\hline \multirow{5}{*}{ Interpersonal } & Intra & 36.36 & 1 & 9.81 & 0.002 & 0.10 & 0.87 & $-2.10 * *(0.54)$ & $-0.92 *(0.29)$ \\
\hline & Intra * Inter & 91.11 & 1 & 24.57 & $<0.001$ & 0.22 & 0.99 & & \\
\hline & Error Intra & 311.38 & 84 & & & & & & \\
\hline & Inter & 189.61 & 1 & 14.75 & $<0.001$ & 0.15 & 0.96 & & \\
\hline & Error Inter & 1079.90 & 84 & & & & & & \\
\hline \multirow{5}{*}{ Stress management } & Intra & 39.40 & 1 & 2.65 & 0.11 & 0.03 & 0.36 & $1.24 *(0.37)$ & $-0.95(0.58)$ \\
\hline & Intra * Inter & 83.77 & 1 & 5.63 & 0.02 & 0.06 & 0.65 & & \\
\hline & Error Intra & 1249.20 & 84 & & & & & & \\
\hline & Inter & 66.21 & 1 & 11.09 & 0.001 & 0.11 & 0.91 & & \\
\hline & Error Inter & 501.55 & 84 & & & & & & \\
\hline \multirow{5}{*}{ Adaptability } & Intra & 96.54 & 1 & 28.85 & $<0.001$ & 0.25 & 1 & $-0.57(0.63)$ & $-1.50 * *(0.27)$ \\
\hline & Intra * Inter & 10.72 & 1 & 3.20 & 0.07 & 0.04 & 0.45 & & \\
\hline & Error Intra & 281.00 & 84 & & & & & & \\
\hline & Inter & 14.20 & 1 & 0.82 & 0.36 & 0.01 & 0.14 & & \\
\hline & Error Inter & 1448.17 & 84 & & & & & & \\
\hline
\end{tabular}


Table 3. Cont.

\begin{tabular}{|c|c|c|c|c|c|c|c|c|c|}
\hline & \multirow[b]{2}{*}{ Source } & \multirow[b]{2}{*}{ Type III } & \multirow[b]{2}{*}{ df } & \multirow[b]{2}{*}{$\mathbf{F}$} & \multirow[b]{2}{*}{ Sig. } & \multirow[b]{2}{*}{$\eta^{2}$ Partial } & \multirow[b]{2}{*}{$\begin{array}{l}\text { Observed } \\
\text { Power }\end{array}$} & \multicolumn{2}{|c|}{ Multiple Comparisons } \\
\hline & & & & & & & & $\begin{array}{l}\text { Group Mean } \\
\text { Difference } \\
\text { (s.e.) }\end{array}$ & $\begin{array}{c}\text { Factor } 1 \text { Mean } \\
\text { Difference } \\
\text { (s.e.) }\end{array}$ \\
\hline \multirow{5}{*}{ Mood } & Intra & 4.74 & 1 & 1.63 & 0.20 & 0.02 & 0.24 & $-0.64(0.51)$ & $-0.33(0.26)$ \\
\hline & Intra * Inter & 15.49 & 1 & 5.34 & 0.02 & 0.06 & 0.63 & & \\
\hline & Error Intra & 243.42 & 84 & & & & & & \\
\hline & Inter & 17.77 & 1 & 1.58 & 0.21 & 0.06 & 0.63 & & \\
\hline & Error Inter & 243.42 & 84 & & & & & & \\
\hline \multirow{5}{*}{ Total CL Efficiency } & Intra & 494.97 & 1 & 129.05 & $<0.001$ & 0.60 & 1 & $-4.75^{* *}(0.68)$ & $-3.39 * *(0.29)$ \\
\hline & Intra * Inter & 766.18 & 1 & 199.75 & $<0.001$ & 0.70 & 1 & & \\
\hline & Error Intra & 322.19 & 84 & & & & & & \\
\hline & Inter & 968.91 & 1 & 48.42 & $<0.001$ & 0.36 & 1 & & \\
\hline & Error Inter & 1680.90 & 84 & & & & & & \\
\hline \multirow{5}{*}{$\begin{array}{l}\text { Interdependence-- } \\
\text { responsibility } \\
\text { dimension }(\mathrm{CL})\end{array}$} & Intra & 162.72 & 1 & 89.97 & $<0.001$ & 0.51 & 1 & $-3.50 * *(0.44)$ & $-1.94^{* *}(0.20)$ \\
\hline & Intra * Inter & 296.86 & 1 & 164.13 & $<0.001$ & 0.66 & 1 & & \\
\hline & Error Intra & 151.93 & 84 & & & & & & \\
\hline & Inter & 527.64 & 1 & 61.98 & $<0.001$ & 0.42 & 1 & & \\
\hline & Error Inter & 715.02 & 84 & & & & & & \\
\hline \multirow{5}{*}{$\begin{array}{l}\text { Communication } \\
\text { dimension }(C L)\end{array}$} & Intra & 90.09 & 1 & 77.60 & $<0.001$ & 0.48 & 1 & $-1.24 *(0.35)$ & $-1.44^{* *}(0.16)$ \\
\hline & Intra * Inter & 109.21 & 1 & 94.07 & $<0.001$ & 0.53 & 1 & & \\
\hline & Error Intra & 97.51 & 84 & & & & & & \\
\hline & Inter & 66.53 & 1 & 12.42 & 0.001 & 0.13 & 0.93 & & \\
\hline & Error Inter & 449.91 & 84 & & & & & & \\
\hline \multirow{5}{*}{$\begin{array}{l}\text { Total classroom } \\
\text { climate }\end{array}$} & Intra & 990.03 & 1 & 85.31 & $<0.001$ & 0.50 & 1 & $-7.45^{* *}(1.12)$ & $-4.80 * *(0.52)$ \\
\hline & Intra * Inter & 2087.00 & 1 & 179.84 & $<0.001$ & 0.68 & 1 & & \\
\hline & Error Intra & 974.79 & 84 & & & & & & \\
\hline & Inter & 2387.07 & 1 & 44.24 & $<0.001$ & 0.68 & 1 & & \\
\hline & Error Inter & 974.79 & 84 & & & & & & \\
\hline \multirow{5}{*}{$\begin{array}{l}\text { Interest dimension } \\
\text { (classroom climate) }\end{array}$} & Intra & 18.97 & 1 & 17.97 & $<0.001$ & 0.17 & 0.98 & $-0.99 *(0.32)$ & $-0.66^{* *}(0.15)$ \\
\hline & Intra * Inter & 61.95 & 1 & 58.67 & $<0.001$ & 0.41 & 1 & & \\
\hline & Error Intra & 88.69 & 84 & & & & & & \\
\hline & Inter & 42.39 & 1 & 9.47 & 0.003 & 0.10 & 0.86 & & \\
\hline & Error Inter & 376.04 & 84 & & & & & & \\
\hline \multirow{5}{*}{$\begin{array}{c}\text { Satisfaction } \\
\text { dimension } \\
\text { (classroom climate) }\end{array}$} & Intra & 86.46 & 1 & 34.67 & $<0.001$ & 0.29 & 1 & $-1.62 * *(0.38)$ & $-1.42^{* *}(0.24)$ \\
\hline & Intra * Inter & 168.29 & 1 & 67.49 & $<0.001$ & 0.44 & 1 & & \\
\hline & Error Intra & 209.45 & 84 & & & & & & \\
\hline & Inter & 113.29 & 1 & 17.46 & $<0.001$ & 0.17 & 0.98 & & \\
\hline & Error Inter & 544.87 & 84 & & & & & & \\
\hline \multirow{5}{*}{$\begin{array}{c}\text { Relationship } \\
\text { dimension } \\
\text { (classroom climate) }\end{array}$} & Intra & 137.76 & 1 & 120.74 & $<0.001$ & 0.59 & 1 & $-2.46^{* *}(0.36)$ & $-1.79^{* *}(0.16)$ \\
\hline & Intra * Inter & 262.79 & 1 & 230.32 & $<0.001$ & 0.73 & 1 & & \\
\hline & Error Intra & 95.84 & 84 & & & & & & \\
\hline & Inter & 261.18 & 1 & 46.42 & $<0.001$ & 0.35 & 1 & & \\
\hline & Error Inter & 472.61 & 84 & & & & & & \\
\hline \multirow{5}{*}{$\begin{array}{l}\text { Communication } \\
\text { dimension } \\
\text { (classroom climate) }\end{array}$} & Intra & 36.88 & 1 & 58.41 & $<0.001$ & 0.41 & 1 & $-2.37^{* *}(0.28)$ & $-0.92 * *(0.12)$ \\
\hline & Intra * Inter & 74.46 & 1 & 117.94 & $<0.001$ & 0.58 & 1 & & \\
\hline & Error Intra & 53.03 & 84 & & & & & & \\
\hline & Inter & 241.54 & 1 & 69.25 & $<0.001$ & 0.45 & 1 & & \\
\hline & Error Inter & 292.98 & 84 & & & & & & \\
\hline
\end{tabular}

Note: $\mathrm{df}=$ degrees of freedom; s.e. $=$ standard error; Sig. = significance; ${ }^{*}=$ significance (Sidak correction for multiple comparisons) $<0.05$;

** = significance (Sidak correction for multiple comparisons) $<0.001$.

Figure 1 shows graphs of the interactions between the groups (experimental and control) for the different variables.

In reference to the programme evaluation questionnaire, the mean scores of all items increased in the post-test situation. The items that showed the greatest increase were those referring to the ability to resolve conflicts that occur in classroom (pretest: mean $=2.67$, $\mathrm{sd}=0.57$; posttest: mean $=4.00, \mathrm{sd}=0.45$ ), the ability to offer students options to work in groups (pretest: mean $=2.00, \mathrm{sd}=1.00$; posttest: mean $=4.33$, $\mathrm{sd}=0.57$ ) and the relationship and communication with families (pretest: mean $=2.67, \mathrm{sd}=1.53$; posttest: mean $=4.00$, $\mathrm{sd}=1.00)$. 
In the satisfaction questionnaire, the highest scores are those referred to in the items of cooperative learning (mean $=5.00, \mathrm{sd}=0.46$ ), and the lowest scores are those referred to in the usefulness of the contents of emotional intelligence (mean $=4.00, \mathrm{sd}=1.00$ ).

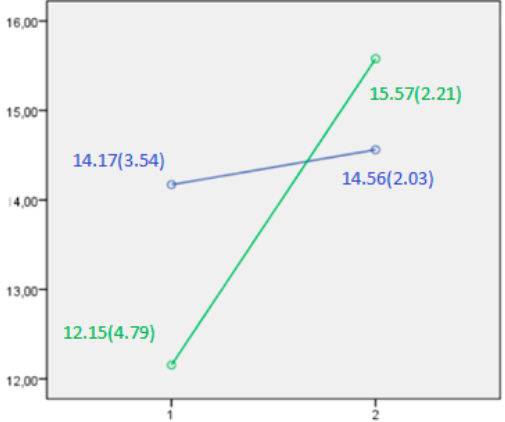

(a.1)

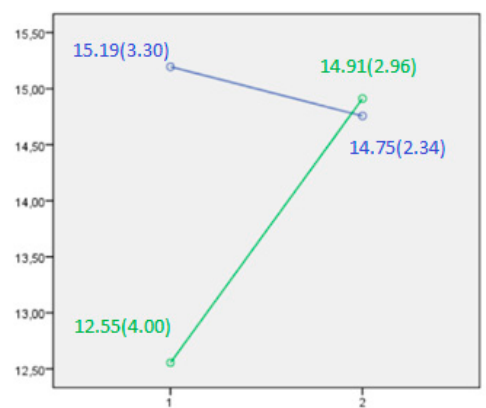

(a.3)

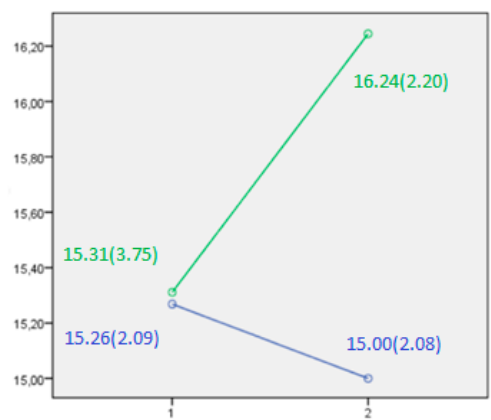

(a.5)

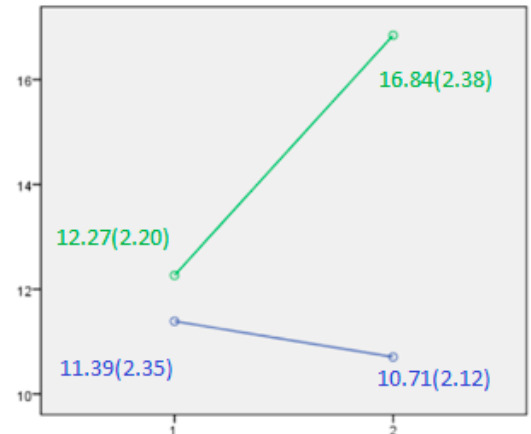

(b.2)

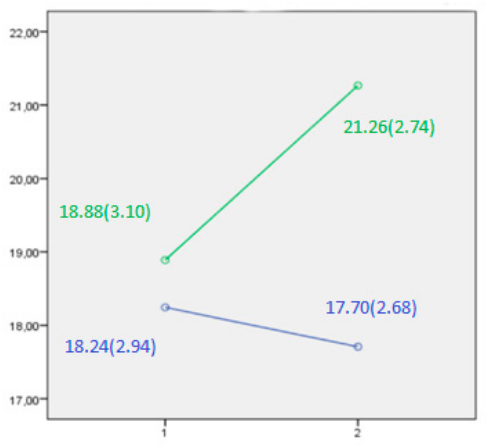

(a.2)

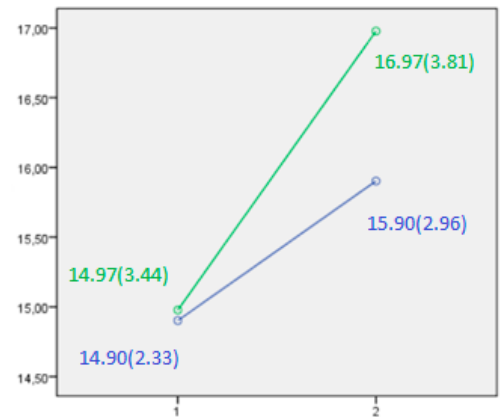

(a.4)

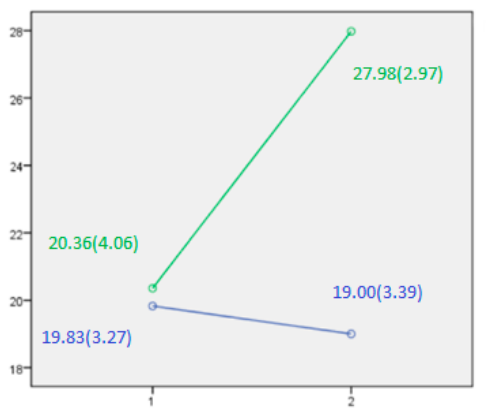

(b.1)

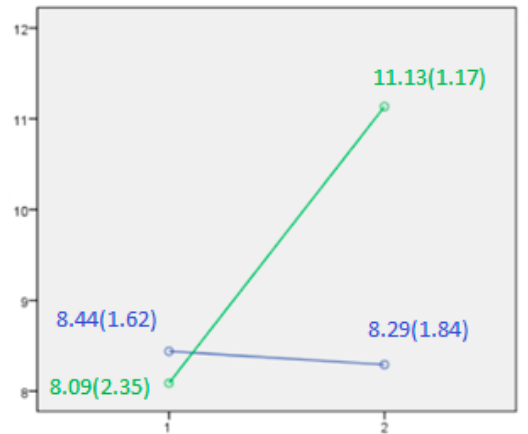

(b.3)

Figure 1. Cont. 


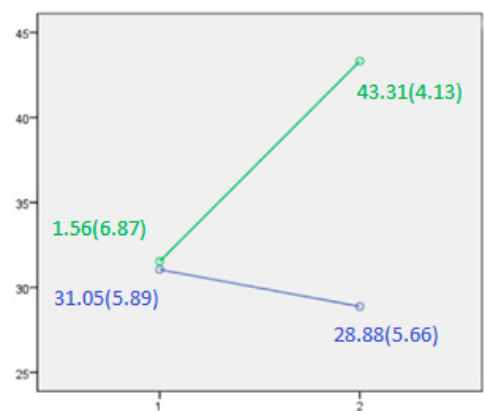

(c.1)

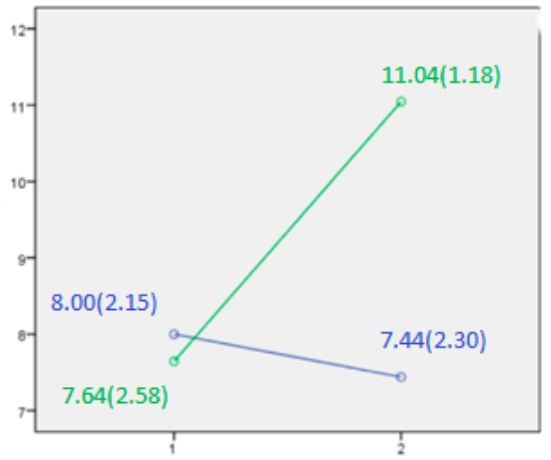

(c.3)

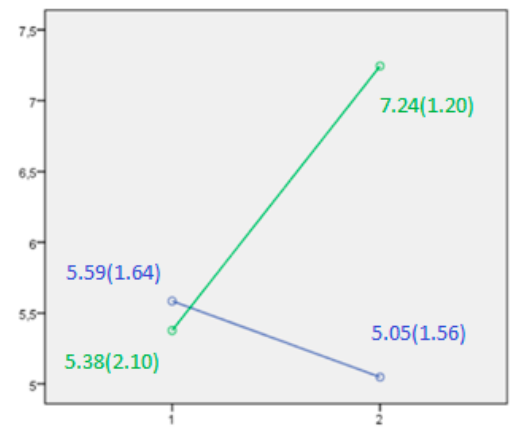

(c.2)

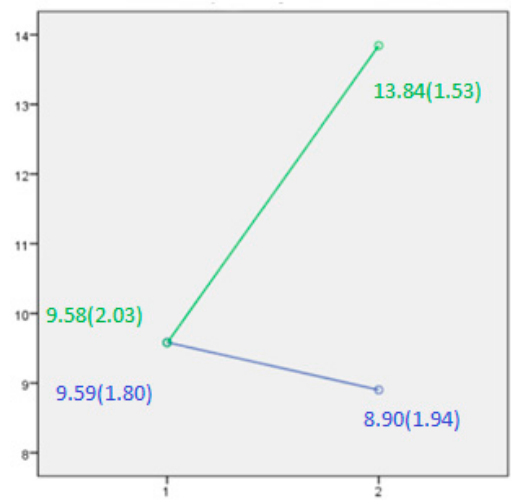

(c.4)

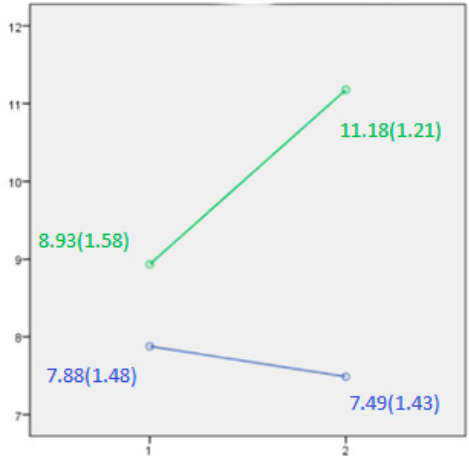

(c.5)

Figure 1. Estimated marginal means for (a.1) intrapersonal; (a.2) interpersonal; (a.3) stress management; (a.4) adaptability; (a.5) mood; (b.1) total CL efficiency; (b.2) interdependence-responsibility dimension (CL); (b.3) communication dimension (CL); (c.1) total classroom climate; (c.2) interest dimension (classroom climate); (c.3) satisfaction dimension (classroom climate); (c.4) relationship dimension (classroom climate); and (c.5) communication dimension (classroom climate). Blue line = control group; Green line = experimental group; mean (standard deviation).

\section{Discussion}

This study describes and evaluates a programme developing socio-emotional skills and the improvement of school climate. It is based on a cooperative methodology that has been conducted by the teachers participating in the research. The study primarily aims to explore the development of EI and how this development influences both cooperative skills and the classroom climate.

The discussion is organised according to the objectives of the research. These refer to the effectiveness of the designed intervention programme, OKAPI, on the different variables raised in the study: improvement in socio-emotional skills (Hypothesis 1); im- 
provement in the effectiveness of cooperative work (Hypothesis 2); and improvement in perceived class climate (Hypothesis 3).

Hypothesis $\mathbf{1}$ (H1). The intervention group significantly improves the development of socioemotional skills in the post-test time; differences linked to participation in the intervention programme are identified.

Notably, the hypothesis is accepted for the interpersonal, intrapersonal, mood and stress management dimensions. However, no significant differences were observed in the adaptability dimension. This is in line with previous research [65], in which results showed that the adaptability dimension was the only one that did not improve in similar programmes. The effect lasted no more than a year, possibly due to changes-both organisational and methodological — that have been conducted, resulting in the requirement of more adaptation time.

In general, it can be concluded that the OKAPI intervention programme improved the students' socioemotional skills, thus agreeing with the authors who state that emotions can be worked on and developed through an emotional education programme $[16,41,66]$. This is in line with the conclusions of authors such as Greenberg et al. [54] After analysing different programmes, these researchers stated that emotional skills improve when they are taught gradually and systematically, and as long as the programmes can offer situations that allow the exercise of emotional skills, which require practice in order to be achieved by students.

Simultaneously, the programme is based on cooperative learning, which has been linked to the improvement of emotional intelligence in previous research $[67,68]$.

Hypothesis 2 (H2). The experimental group significantly improves the effectiveness of cooperative work in the post-test time; differences linked to participation in the intervention programme are identified.

Our analysis showed that the interaction between the time of the evaluation (pre-test and post-test) and programme implementation was significant with respect to both the total scale and its individual dimensions (communication, interdependence, and responsibility), with adequate power and effect size. This allows for the acceptance of the hypothesis.

The use of cooperative learning as a basis for the implementation of the OKAPI programme was based on several studies related to the use of this methodology in improving numerous aspects that influence the teaching-learning process of students. Cooperative learning represents a good opportunity to practice socioemotional skills $[32,37,65,67]$, as it encourage social interactions.

The results obtained after programme application are in line with other studies on the effects of cooperative learning in the school environment. When students improve their cooperative skills, they also learn how to establish healthier relationships with others. Further, this results in a decrease in disruptive behaviours and improved coexistence in the school [69].

Hypothesis 3 (H3). The intervention group shows a significant improvement in class climate as perceived post-test; differences linked to participation in the intervention programme are identified.

This hypothesis is also accepted, as the values resulting from our analysis show how the implementation of the interaction between the time of evaluation (pre-test and posttest) and the implementation of the programme were significant with respect to both the total scale and its dimensions (communication and interdependence-responsibility), with adequate power and effect size.

The improvement of the classroom climate perceived through the OKAPI programme is in line with several studies that link this improvement to organisational aspects [23] of cooperative learning [37] or the incorporation of students' socio-emotional competence [70,71]. 
The classroom climate and students' socio-emotional skills are closely related factors, as there is a strong relationship between the development of understanding of the consequences of one's behaviour-an aspect addressed in part by organisation and coexistence in the OKAPI programme-and overall emotional regulation [57,72]. If students can control their attention and inhibit impulsive responses, they will have fewer problems, and disruptive behaviours will decrease [73], which will directly and positively affect the perceived classroom climate.

\section{Conclusions}

This study aimed to observe the effectiveness of the OKAPI programme on the development of students' socioemotional skills, the improvement of the classroom climate, and the development of cooperative competencies. The results allow us to state that the improvements appreciated due to the conducted intervention. We therefore conclude that the implementation of the programme was effective for both the improvement of the classroom climate and the acquisition of training in the field of emotional intelligence, as well as for the development of cooperative competence.

The programme combines interventions intended to improve the classroom climate with socioemotional education. These aspects have traditionally been implemented and studied from different perspectives, generating varied theoretical frameworks and limiting the effects of programmes that have treated them separately [74].

A positive environment based on values such as solidarity, trust, and mutual support simultaneously generates a positive classroom climate and opportunities to develop socioemotional skills. Moreover, a positive school climate is favourable to the development of these competencies [75]. Both theoretical bodies have been joined in developing this programme design due to their close relationship. Based on the results of this study as observed in the analysis of the correlations, EI maintained positive and significant connections with the class climate.

Among the fundamental pillars of the OKAPI programme are its simplicity and transversality, as teachers are responsible for its application and monitoring. Thus, the programme becomes an agent of change in their own educational practice. Merrell [76], the creator of the Strong Kids programme, points out that overly complex programmes with complicated theoretical frameworks require extensive preparation and are associated with high financial costs that schools often cannot cope with. In fact, after implementing certain programmes schools sometimes observe that they do not receive the expected benefits [77], likely due to programme complexity or incorrect implementation as a consequence.

It is essential that such programmes be conducted by teachers, specifically by tutors, as research has shown that programmes taught and reinforced by tutors are more effective $[16,54]$ than those conducted by experts outside the educational centre or classroom. Moreover, having to resort to external staff may result in teachers seeing the programme as an alien issue that does not adapt to their own context or needs [17].

Another principle followed by the programme has been transversality. Essentially all of the designed activities comprise tools that can be used in all subjects, in all of the school's spaces, and by everyone in the educational community. Furthermore, we have tried to include specific activities in classroom routines and schedules.

Following Berrocal and Rioz Aranda [78], the teaching of socioemotional skills depends primarily on practice, training, and improvement, and not as much on verbal instruction. In other words, what is important is to practice these skills in various contexts, with the classroom providing situations for this to take place.

Children spend much of the day in school, which is why it must be ensured that the environment is positive and promotes optimal development $[71,75,79]$. Achieving this goal involves global changes capable of modifying practices and providing strategies that can be integrated into the school. This aspect in particular frames this study, similarly to existing research, as marking a key premise that programmes for emotional education 
must go hand in hand with programmes for the improvement of the classroom or school climate [80].

In conclusion, this study provides a new programme to develop the socioemotional skills of primary school students while also serving as a tool to improve the classroom climate, promote a methodological change oriented towards cooperation, and encourage the participation and involvement of the educational community. The common goal is to achieve an open, inclusive, and flexible school capable of welcoming the whole community, where each member can find a favourable environment to develop.

\section{Limitations and Future Research}

In the following section, some of the limitations of this study will be stated, which can also serve as a guide for future research.

First, the transferability of the results due to the method of sample selection must be highlighted. The sample was selected based on accessibility, and groups that were already formed were considered without being able to make use of a random process; therefore, the sample cannot be considered fully representative. Another limitation can be found in the evaluation of the different variables. In fact, data were collected through self-reported measures, which can produce subjective and biased information.

Based on the research results of the present study, areas of research that could be further developed are identified. For example, to ensure the transferability of results the OKAPI programme should be implemented in different schools using a much larger sample of students. Another aspect to consider would be to check the sustainability of the results, that is, to carry out a longitudinal study in an educational centre for at least six years. This would allow for more time, and for the graduation of primary school children who have participated in the programme throughout their school path. Moreover, linked to this feature is the aspect of permanence. That is, to check whether the improvements that the students have experienced last following the full realisation of the program. With regard to the instruments used, it would be useful to incorporate measurement tools for EI skills, as well as 360-degree observations involving families, classmates, teachers, and students.

Author Contributions: Conceptualisation, M.-J.M.-G. and R.G.-C.; methodology, R.G.-C.; investigation, M.-J.M.-G.; resources, R.G.-C.; data curation, M.-J.M.-G.; writing-original draft preparation, M.-J.M.-G. and R.G.-C.; funding acquisition, R.G.-C. All authors have read and agreed to the published version of the manuscript.

Funding: This research was supported by the Spanish Ministry of Economy and Competitiveness (EDU2015-64562-R).

Institutional Review Board Statement: The study was conducted according to the guidelines of the Declaration of Helsinki, and approved by the Ethics Committee of UNIVERSITY OF ALICANTE (protocol code UA-2015-07-06 and date of approval: 2015).

Informed Consent Statement: Informed consent was obtained from all subjects involved in the study.

Data Availability Statement: Data are available on request from the authors.

Acknowledgments: We are thankful to the editors and three anonymous reviewers for their helpful comments. They helped to significantly improve the presentation and discussion of our topic.

Conflicts of Interest: The authors declare no conflict of interest.

\section{References}

1. Brackett, M.A.; Mayer, J.D. Convergent, discriminant and incremental validity of competing measures of emotional intelligence. Pers. Soc. Psychol. Bull. 2003, 29, 1-12. [CrossRef]

2. CASEL (Collaborative for Academic, Social and Emotional Learning). Available online: https://casel.org/fundamentals-of-sel/ what-does-the-research-say/ (accessed on 27 September 2021). 
3. Extremera, N.; Fernández-Berrocal, P. ¿Es la Inteligencia Emocional un Adecuado Predictor del Rendimiento Académico en Estudiantes? In Jornadas de Innovación Pedagógica; Inteligencia Emocional; Una brújula para el siglo XXI: Granada, Spain, 2001; pp. 146-157.

4. $\quad$ Fernández-Berrocal, P.; Berrios-Martos, M.P.; Extremera, N.; Augusto, J.M. Inteligencia emocional: 22 años de avances empíricos. Psicol. Conduct. 2012, 20, 5-13.

5. Gil-Olarte, P.; Guil, R.; Mestre, J.M.; i Núñez, I. La Inteligencia Emocional Como Variable Predictora del Rendimiento Académico. In Psicología Social y Problemas Sociales; Psicología, A., Comunitaria, Y.E., Romay, J., García, R., Eds.; Biblioteca Nueva: Madrid, Spain, 2005; pp. 35-357; ISBN 84-9742-454-9.

6. Pérez, N.; Castejón, J.L. La Inteligencia Emocional como predictor del rendimiento académico en estudiantes universitarios. Ansiedad Y Estrés 2007, 12, 121-131.

7. Petrides, K.V.; Frederickson, N.; Furnham, A. The role of trait emotional intelligence in academic performance and deviant behavior at school. Personal. Individ. Differ. 2004, 36, 277-293. [CrossRef]

8. Gilar-Corbi, R.; Pozo-Rico, T.; Castejón, J.L.; Sánchez, T.; Sandoval, I.; Vidal, J. Academic Achievement and Failure in University Studies: Motivational and Emotional Factors. Sustainability 2020, 12, 9798. [CrossRef]

9. Pozo-Rico, T.; Gilar-Corbí, R.; Izquierdo, A.; Castejón, J.L. Teacher Training Can Make a Difference: Tools to Overcome the Impact of COVID-19 on Primary Schools. An Experimental Study. Int. J. Environ. Res. Public Health 2020, 17, 8633. [CrossRef] [PubMed]

10. Brackett, M.A.; Rivers, S.; Shiffman, S.; Lerner, N.; Salovey, P. Relating Emotional Abilities to Social Functioning: A Comparison of Self-Report and Performance Measures of Emotional Intelligence. J. Pers. Soc. Psychol. 2006, 91, 780-795. [CrossRef] [PubMed]

11. Extremera, N.; Fernández-Berrocal, P. El uso de las medidas de habilidad en el ámbito de la inteligencia emocioal. Ventajas e inconvenientes con respecto a las medidas de auto-informe. Bol. De Psicol. 2004, 80, 59-77.

12. Mestre, J.; Guil, R.; Lopes, P.; Salovey, P.; Gil-Olarte, P. Emotional intelligence and social and academic adaptation to school. Psicothema 2006, 18, 112-117.

13. Fernández-Berrocal, P.; Alcaide, R.; Extremera, N.; Pizarro, D.A. The role of emotional intelligence in anxiety and depression among adolescents. Individ. Differ. Res. 2006, 4, 16-27.

14. Salovey, P.; Stroud, L.R.; Woolery, A.; Epel, E.S. Perceived emotional intelligence, stress reactivity, and symptom reports: Further explorations using the trait meta-mood scale. Psychol. Health 2002, 17, 611-627. [CrossRef]

15. Pozo-Rico, T.; Sandoval, I. Can academic achievement in primary school students be improved through teacher training on Emotional Intelligence as a Key Academic Competency? Front. Psychol. 2020, 10, 2976. [CrossRef] [PubMed]

16. Durlak, J.A.; Weissberg, R.P.; Dymnicki, A.B.; Taylor, R.D.; Schellinger, K.B. The impact of enhancing students' social and emotional learning: A meta-analysis of school-based universal interventions. Child Dev. 2011, 82, 405-432. [CrossRef]

17. Jones, S.M.; Bouard, S. Social and emotional learning in schools: From programs to strategies. Soc. Policy Rep. 2012, 23, 1-33. [CrossRef]

18. Comer, J.P.; Emmons, C. The research program of the Yale Child Study Center School Development Program. J. Negro Educ. 2006, $75,353-372$.

19. Thapa, A.; Cohen, J.; Guey, S.; Higgins-D'Alessandro, A. A review of school climate research. Rev. Educ. Res. 2013, 83, 357-385. [CrossRef]

20. Cohen, J.; McCabe, L.; Michelli, N.M.; Pickeral, T. School climate: Research, policy, practice, and teacher education. Teach. Coll. Rec. 2009, 111, 180-213.

21. Bar-On, R. EQ-i: The Bar-On model of emotional-social intelligence (ESI). Psicothema 2002, 18, $13-25$.

22. Bisquerra, R. Educación Emocional y Benestar; Praxis: Barcelona, Spain, 2000; ISBN 9788471978769.

23. Molina, N.; Pérez, I. El clima de relaciones interpersonales en el aula un caso de estudio. Rev. Paradig. 2006, $27,193-219$.

24. Hernández, F.; Sancho, J.M. El Clima Escolar en Los Centros de Secundaria: Más Allá de Los Tópicos; Secretaría General Técnica (MEC): Madrid, Spain, 2004; ISBN 84-369-3952-2.

25. Marchena, R. El ambiente en las clases de Matemáticas y la respuesta a las diferencias individuales. Bordón. Soc. Española De Pedagog. 2005, 57, 197-210.

26. Kagan, S. Cooperative Learning; Kagan Pub: San Clemente, CA, USA, 1994; ISBN 978-1879097100.

27. Pujolàs, P. Atención a la Diversidad y Aprendizaje Cooperativo en la Educación Obligatòria; Aljibe: Málaga, Spain, 2001; ISBN 84-9700-010-2.

28. Pujolàs, P.; Lago, J.R. El Programa CA/AC per a Ensenyar a Aprendre en Equip. Available online: https://cife-ei-caac.com/es / programa-2/ (accessed on 27 September 2021).

29. Beltrán, J.; Bueno, J.A. Psicología de la Educación; Boixareu Universitaria: Barcelona, Spain, 1995; ISBN 9788426710338.

30. Brunner, J.S. Desarrollo Cognitivo y Educación, 10th ed.; Morata: Madrid, Spain, 1988; ISBN 8471123193.

31. Cid, A. El clima escolar como factor de calidad en los centros de educación secundaria de la provincia de Orense. Su estudio desde la perspectiva de la salud. Rev. De Investig. Educ. 2004, 22, 113-144.

32. Ovejero, A. El Aprendizaje Cooperativo; Una Alternativa Eficaz a la Enseñanza Tradicional PPU: Barcelona, Spain, 2009; ISBN 9788476657720 .

33. Wells, C.V.; Grabert, C. Service-learning and mentoring: Effective pedagogical strategies. Coll. Stud. J. 2004, 38, 573-578.

34. Perkins, D. Outsmarting IQ: The Emerging Science of Learnable Intelligence; The Free Press: New York, NY, USA, 1995; ISBN 9780029252123. 
35. Ovejero, A. Aprendizaje cooperativo: Una eficaz aportación de la psicología social a la escuela del siglo XXI. Psicothema 1993, 5, 373-391.

36. Diaz-Aguado, M.J. Prevenir la Violencia Contra las Mujeres Construyendo la Igualdad Desde la Educación; Instituto de la Mujer: Madrid, Spain, 2002.

37. Diaz-Aguado, M.J. Educación Intercultural y Aprendizaje Cooperativo; Pirámide: Madrid, Spain, 2003; ISBN 978-84-368-1709-6.

38. Ruiz de Miguel, C.; García, M. Factores relacionados con la calidad en las aulas de educación infantil: Propuesta de un modelo explicativo. Bordón 2004, 56, 317-328.

39. Moos, R.H.; Moos, B.S. Classroom social climate and student absences and grades. J. Educ. Psychol. 1978, 70, 263-269. [CrossRef]

40. Moos, R.H.; Trickett, E.J. Classroom Environment Scale Manual, 2nd ed.; Consulting Psychologist Press: Palo Alto, CA, USA, 1987.

41. Bisquerra, R. Orientación, Tutoría y Educación Emocional; Síntesis: Madrid, Spain, 2013; ISBN 978-84-995892-5-1.

42. Carbonero, M.A.; Martín-Antón, L.J.; Román, J.M.; Reoyo, N. Efecto de un programa de entrenamiento al profesorado en la motivación, clima de aula y estrategias de aprendizaje de su alumnado. Rev. Iberoam. De Psicol. Y Salud 2010, 1, 117-138.

43. Martin, A.J.; Dowson, M. Interpersonal Relationships, Motivation, Engagement, and Achievement. Rev. Educ. Res. 2009, 79, 327-365. [CrossRef]

44. Anderson-Butcher, D.; Newsome, W.S.; Nay, S. Social skills intervention during elementary school recess: A visual analysis. Child. Sch. 2003, 35, 135-146. [CrossRef]

45. Jennings, P.A.; Greenberg, M.T. The Prosocial Classroom: Teacher Social and Emotional Competence in Relation to Student and Classroom Outcomes. Rev. Educ. Res. 2009, 79, 491-525. [CrossRef]

46. Peralta, F.J. Estudio de Los Problemas de Convivencia Escolar en Estudiantes de Enseñanza Secundaria. Ph.D. Dissertation, Universidad de Málaga, Málaga, Spain, 2004.

47. Baker, J.A.; Dilly, L.J.; Aupperlee, J.L.; Patil, S.A. The developmental context of school satisfaction: Schools as psychologically healthy environments. Sch. Psychol. Q. 2003, 18, 206-221. [CrossRef]

48. Manasero, M.A. Estrés y Burnout en la Enseñanza; Edicions UIB: Palma, Spain, 2003; ISBN 978-8476328217.

49. Crosnoe, R.; Kirkpatrick, M.; Elder, G.H. School Size and the Interpersonal Side of Education: An Examination of Race/ethnicity and Organizational Context. Soc. Sci. Quartely 2004, 85, 1259-1274. [CrossRef]

50. Pieron, M. Para Una Enseñanza Eficaz de Las Actividades Físico-Deportivas; Inde: Barcelona, Spain, 1999 ; ISBN 9788487330988.

51. Villa, A.; Villar, L.M. Clima Organizativo y de Aula: Teoría y Modelos e Instrumentos Para su Medida; Servicio Central de Publicaciones del Gobierno Vasco: Victoria-Gasteiz, Spain, 1992; ISBN 84457014609788445701461.

52. Hatzenbuehler, M.L.; Birkett, M.; Van Wagenen, A.; Meyer, I.H. Protective school climates and reduced risk for suicide ideation in sexual minority youths. Am. J. Public Health 2014, 104, 279-286. [CrossRef]

53. Osher, D.; Dwyer, K.; Jackson, S. Safe, Supportive and Successful Schools Step by Step; Sopris West: Longmont, CO, USA, 2004; ISBN 978-1570359187.

54. Greenberg, M.T.; Weissberg, R.P.; O’Brien, M.U.; Zins, J.E.; Fredericks, L.; Resink, H.; Elias, M.J. Enhancing School-Based Prevention and Youth Development Though Coordinated Social, Emotional, and Academic Learning. Am. Psychol. 2003, 58, 466-474. [CrossRef] [PubMed]

55. Elousa, P.; Zumbo, B. Coeficientes de fiabilidad para escalas de respuesta categórica ordenada. Psicothema 2008, 20 , 896-901.

56. Pérez, A.; Ramos, G.; López, E. Diseño y análisis de una escla para la valoración de la variable clima social aula en alumnos de Educación Primaria y Secundaria. Rev. De Educ. 2009, 350, 221-252.

57. León, B.; Felipe, E.; Iglesias, D.; Marugán de Miguelsanz, M. Determinantes en la Eficacia del Aprendizaje Cooperativo. Una experiencia en el EEES. Rev. De Investig. Educ. 2014, 32, 411-424. [CrossRef]

58. Garcia Gallego, C. Investigación Cuasiexperimental I: Diseños Preexperimentales y Diseños Cuasiexperimentales Con Grupo de Control No Equivalente. In Diseños de Investigación en Psicología; Fontes de Gracia, S., Garcia Gallego, C., Garriga Trillo, A.J., Pérez-Llantada Rueda, M.C., Sarrià Sánchez, E., Eds.; UNED: Madrid, Spain, 2001; pp. 374-378. ISBN 9788436244748.

59. Bryant, J.L.; Paulson, A.S. Extension of Tukey's Method of Multiple Comparisons to Experimental-Designs with Random Concomitant Variables. Biometrika 1976, 63, 631-638. [CrossRef]

60. Defeo, P.; Myers, R.H. A New Look at Experimental-Design Robutness. Biometrika 1992, 79, 375-380. [CrossRef]

61. Freeman, J. Environment and High IQ, a Consideration of Fluid and Crystallized Intelligence. Personal. Individ. Differ. 1973, 4, 307-313. [CrossRef]

62. Vuchkov, I.N.; Solakov, E.B. The Influence of Experimental-Design on Robistness tot Non-Normality of the F-Test in RegressionAnalysis. Biometrika 1980, 67, 489-492. [CrossRef]

63. Gardner, C.R. Estadística Para Psicología Usando SPSS Para Windows; Prentice Hall: México DF, Mexico, 2003 ; ISBN 9789702603474.

64. Hair, J.F., Jr.; Anderson, R.E.; Tatham, R.L.; Black, W.C. Multivariate Data Analysis, 5th ed.; Pearson Prestince Hall: Madrid, Spain, 1999; ISBN 84-8322-035-0.

65. Lara, H.A. Investigaciones recientes sobre adolescencia e inteligencia emocional. Enseñ. E Investig. En Psicol. 2006, 11, $413-416$.

66. Schutte, N.; Malouff, J.M.; Thorsteinsson, E.B. Increasing Emotional Intelligence through Training: Current Status and Future Directions. Int. J. Emot. Educ. 2013, 5, 56-72.

67. Bisquerra, R.; Pérez-González, J.C.; García, E. Inteligencia Emocional en Educación; Síntesis: Madrid, Spain, 2015; ISBN 9788490776308.

68. Petrides, K.V. Trait Emotional Intelligence Theory. Ind. Organ. Psychol. 2010, 3, 136-139. [CrossRef] 
69. García, F.J.; Jiménez, I.; Muñoz, M.V.; Marande, G.; Monjas, M.I.; Sureda, I.; Sanchiz, M.L. El Rechazo Entre Iguales en Su Contexto Interpersonal. Una Investigación Con Niños y Niñas de Primer Ciclo de Primaria; Fundación Dávalos-Fletcher: Castellon, Spain, 2009; ISBN 9788469704936.

70. García-Sancho, E.; Salguero, J.M.; Fernández-Berrocal, P. Ability emotional intelligence and its relation to aggresion across time and age groups. Scand. J. Psychol. 2016, 58, 43-51. [CrossRef] [PubMed]

71. Trianes, M.V. Programa Para El Desarrollo de Relaciones Sociales Competentes en Educación Primaria; Aljibe: Málaga, Spain, 2012; ISBN 9788497007764.

72. Leon-Rodriguez, D.A.; Sierra-Mejía, H. Desarrollo de la comprensión de las consecuencias de las emociones. Rev. Latinoam. De Psicol. 2008, 40, 35-45.

73. Bates, J.; Goodnight, J.A.; Fite, J.E. Temperament and Emotion. In Handbook of Emotions, 3rd ed.; Lewis, M., Haviland-Jones, J., Feldman, L., Eds.; Guilford Press: New York, NY, USA, 2008; pp. 485-496. ISBN 978-1-59385-650-2.

74. Osher, D.; Berg, J. Edna Bennet Pierce Prevention Research Center. Available online: https://www.prevention.psu.edu/uploads/ files/rwjf443059.pdf (accessed on 27 September 2021).

75. Ruvalcaba, N.A.; Gallegos-Guajardo, J.; Fuerte, J.M. Competencias socioemocionales como predictoras de conductas prosociales y clima escolar positivo en adolescentes. Rev. Interuniv. De Form. Del Profr. 2017, 31, 77-90.

76. Merrell, K.W. Linking prevention science and social and emotional learning: The Oregon Resiliency Project. Psychol. Sch. 2010, 47, 55-70. [CrossRef]

77. Banerjee, R.; Weare, K.; Farr, W. Working with 'Social and Emotional Aspects of Learning' (SEAL): Associations with school ethos, pupil social experiences, attendance, and attainment. Br. Educ. Res. J. 2014, 40, 718-742. [CrossRef]

78. Fernández-Berrocal, P.; Ruiz, D. La Inteligencia emocional en la Educación. Electron. J. Res. Educ. Psychol. 2008, 6, 421-436. [CrossRef]

79. Orpinas, P.; Horne, A.M. Bullying Prevention: Creating a Positive School Climate and Developing Social Competence; American Psychological Association: Washington, DC, USA, 2006; ISBN 1-59147-282-2.

80. Jones, S.M.; Bailey, R.; Brion-Meisels, G.; Partee, A. Choosing to be positive. Educ. Leadersh. 2016, 74, 63-68. 